ORNL/TM-2000/324

\title{
Melter Glass Removal And Dismantlement
}

\section{October 2000}

Prepared by:

Bradley S. Richardson

Group Leader 


\section{DOCUMENT AVAILABILITY}

Reports produced after January 1, 1996, are generally available free via the U. S. Department of Energy (DOE) Information Bridge.

Web site http://www.osti.gov/bridge

Reports produced before January 1, 1996, may be purchased by members of the public from the following source.

National Technical Information Services

5285 Port Royal Road

Springfield, VA 22161

Telephone 703-605-6000 (1-800-53-6847)

TDD 703-487-4639

Fax 703-605-6900

E-mail info@ntis.fedworld.gov

Web site http://www.ntis.gov/support/ordernowabout.htm

Reports are available to DOE employees, DOE contractors, Energy Technology Data Exchange (ETDE) representatives, and International Nuclear Information System (INIS) representatives from the following source.

Office of Scientific and Technical Information

P.O. Box 62

Oak Ridge, TN 37831

Telephone 865-576-8401

Fax 865-576-5728

E-mail reports@adonis.osti.gov

Web site http://www.osti.gov/contact.html

This report was prepared as an account of work sponsored by an agency of the United States Government. Neither the United States government nor any agency thereof, nor any of their employees, makes any warranty, express or implied, or assumes any legal liability or responsibility for the accuracy, completeness, or usefulness of any information, apparatus, product, or process disclosed, or represents that its use would not infringe privately owned rights. Reference herein to any specific commercial product, process, or service by trade name, trademark, manufacturer, or otherwise, does not necessarily constitute or imply its endorsement, recommendation, or favoring by the United States Government or any agency thereof. The views and opinions of authors expressed herein do not necessarily state or reflect those of the United States Government or any agency thereof. 


\title{
Melter Glass Removal and Dismantlement
}

\author{
Bradley S. Richardson \\ Oak Ridge National Laboratory \\ P. O. Box 2008 \\ Oak Ridge, Tennessee 37831-6426
}

Published: October 2000

\author{
Prepared by \\ OAK RIDGE NATIONAL LABORATORY \\ P.O. Box 2008 \\ Oak Ridge, Tennessee 37831-6285 \\ managed by \\ UT-Battelle, LLC, \\ for the \\ U.S. DEPARTMENT OF ENERGY \\ under contract DE-AC05-00OR22725
}





\section{CONTENTS}

LIST OF FIGURES..................................................................................................................................... V

LIST OF TABLES................................................................................................................. VII

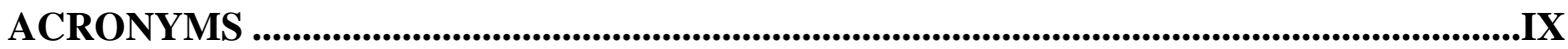

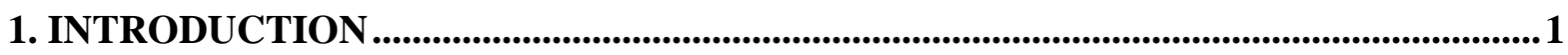

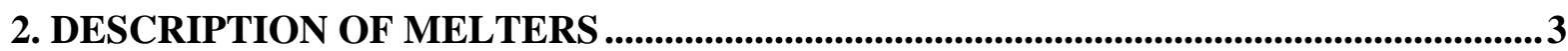

2.1 WVDP

2.2 DEFENSE WASTE PROCESSING FACILITY (DWPF) ………................................ 4

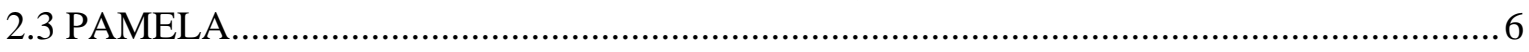

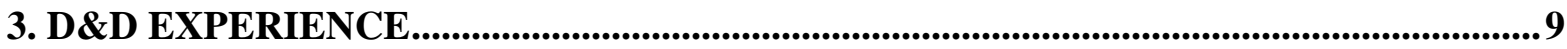

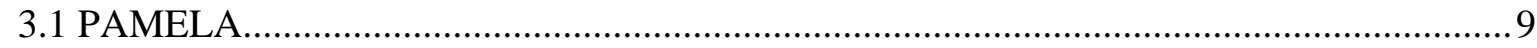

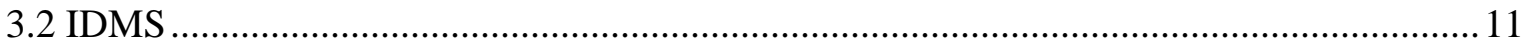

3.3 RELEVANT DOE D\&D ACTIVITIES ...................................................................... 11

3.3.1 Chicago-Pile No. 5 (CP-5) D\&D ...................................................................... 11

3.3.2 Size-Reduction of the Tokamak Fusion Test Reactor Vacuum Vessel........................13

3.3.3 Modified Brokk Demolition Machine with Remote Console ...................................... 15

3.3.4 Other D\&D Focus Area Supported Demonstrations...................................................... 17

4. COMMERCIAL CAPABILITIES ........................................................................................... 19

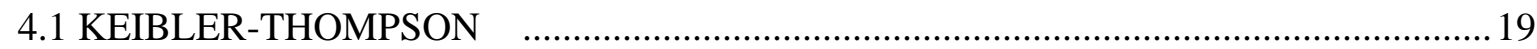

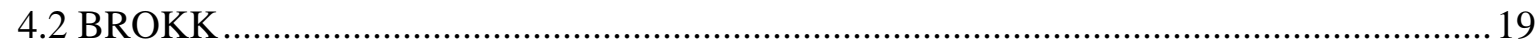

4.3 BLUEGRASS CONCRETE CUTTING, INC. ........................................................... 21

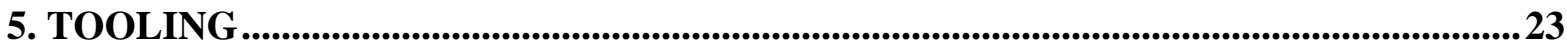

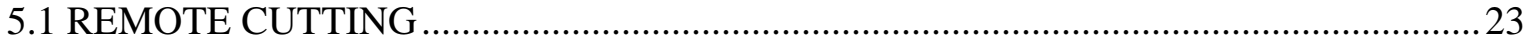

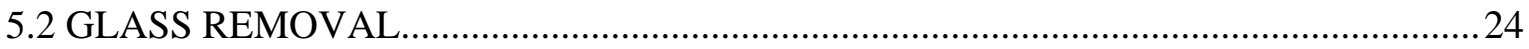

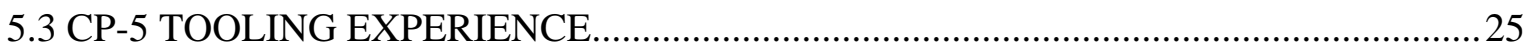

6. DISPENSATION OPTIONS ............................................................................................27

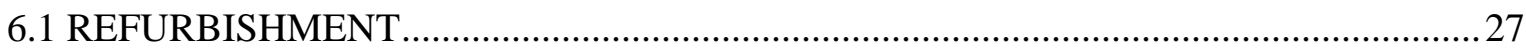

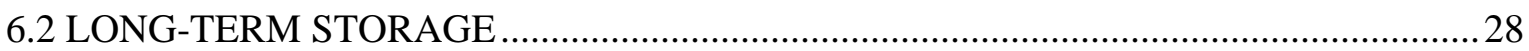

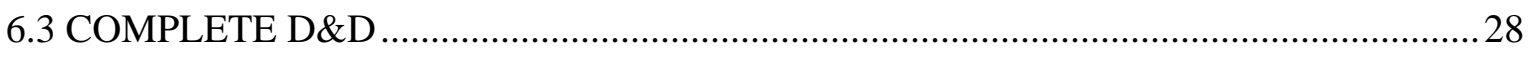

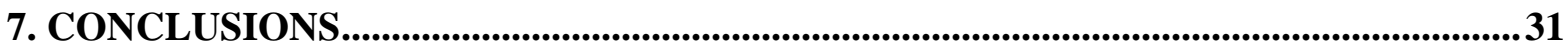

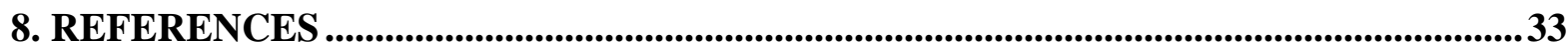




\section{LIST OF FIGURES}

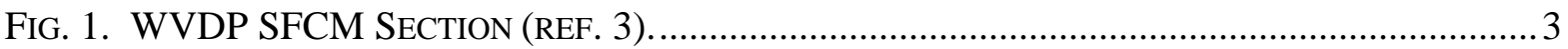

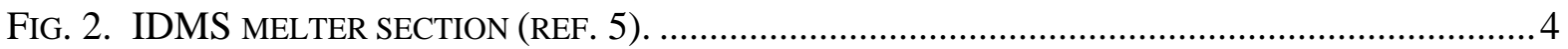

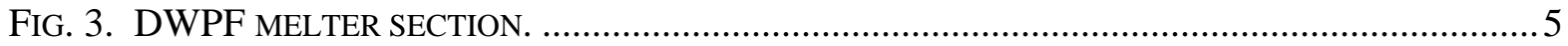

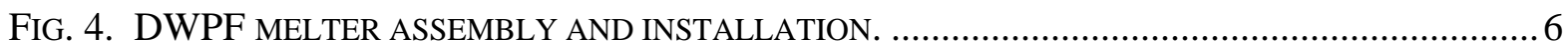

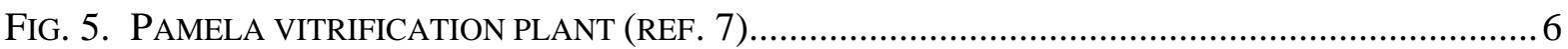

Fig. 6. CROSS SECTION OF THE PAMELA MELTER (REF. 7) ....................................................... 7

FIG. 7. MELTER CELL SCHEMATIC (REF. 7) …..................................................................... 9

FIG. 8. SCHEMATIC OF THE CP-5 RESEARCH REACTOR.......................................................... 12

FIG. 9. DAWP WORKING ABOVE THE CP-5 RESEARCH REACTOR ......................................... 13

FIG. 10. TFTR DIAMOND WIRE CUTTING SETUP (REF. 9) ......................................................... 13

FIG. 12. FILLED VACUUM VESSEL AND WIRE AND PULLEYS SETUP (REF. 9) ............................ 14

FIG. 13. MODIFIED BROKK PERFORMING FACILITY D\&D TASK (REF. 12) .................................. 16

FIG. 14. COMPACT CONSOLE CONTROLLING THE MODIFIED BROKK (REF. 12) ............................. 17

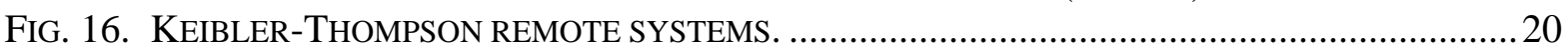

FIG. 17. BROKK REMOTE-CONTROLLED SYSTEM PERFORMING D\&D TASKS. ............................2

FIG. 18. CONDENSER CUT USING DIAMOND WIRE CUTTING................................................. 21 


\section{LIST OF TABLES}

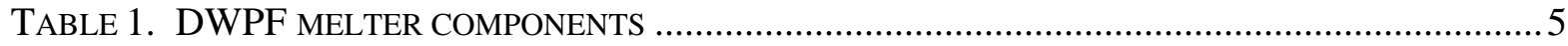

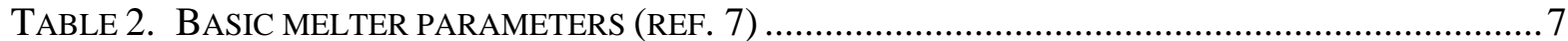

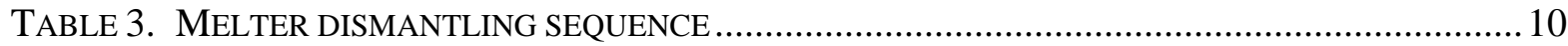

TABLE 4. CUTTING RATES FOR STAINLESS STEEL …............................................................... 10

TABLE 5. LESSONS LEARNED FROM DISMANTLING OF PAMELA MELTER...................................... 11

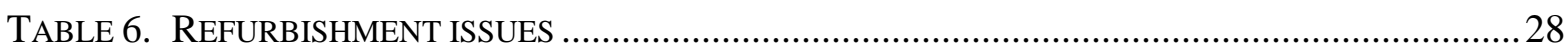




\section{ACRONYMS}

$\begin{array}{ll}\text { ANL } & \text { Argonne National Laboratory } \\ \text { CRC } & \text { Compact Remote Console } \\ \text { D\&D } & \text { Decontamination and Decommissioning } \\ \text { DAWP } & \text { Dual Arm Work Platform } \\ \text { DAWM } & \text { Dual Arm Work Module } \\ \text { DOE } & \text { U. S. Department of Energy } \\ \text { DOF } & \text { Degree-of-Freedom } \\ \text { DWPF } & \text { Defense Waste Processing Facility } \\ \text { FACTS } & \text { Functional and Checkout Testing of Systems } \\ \text { HLW } & \text { High-Level Waste } \\ \text { IDMS } & \text { Integrated DWPF Melter System } \\ \text { INEEL } & \text { Idaho National Environmental and Engineering Laboratory } \\ \text { ORNL } & \text { Oak Ridge National Laboratory } \\ \text { PPPL } & \text { Princeton Plasma Physics Laboratory } \\ \text { REDC } & \text { Remote Equipment Decontamination Cell } \\ \text { RF } & \text { Radio Frequency } \\ \text { SFCM } & \text { Slurry-Fed Ceramic Melter } \\ \text { SRS } & \text { Savannah River Site } \\ \text { STF } & \text { South Tank Farm } \\ \text { TFTR } & \text { Tokamak Fusion Test Reactor } \\ \text { WVDP } & \text { West Valley Demonstration Project }\end{array}$




\section{INTRODUCTION}

The U.S. Department of Energy (DOE) has been using vitrification processes to convert highlevel radioactive waste forms into a stable glass for disposal in waste repositories. Vitrification facilities at the Savannah River Site (SRS) and at the West Valley Demonstration Project (WVDP) are converting liquid high-level waste (HLW) by combining it with a glass-forming media to form a borosilicate glass, which will ensure safe long-term storage. Large, slurry fed melters, which are used for this process, were anticipated to have a finite life (on the order of two to three years) at which time they would have to be replaced using remote methods because of the high radiation fields. In actuality the melters useable life spans have, to date, exceeded original life-span estimates.

Initial plans called for the removal of failed melters by placing the melter assembly into a container and storing the assembly in a concrete vault on the vitrification plant site pending sizereduction, segregation, containerization, and shipment to appropriate storage facilities. Separate facilities for the processing of the failed melters currently do not exist. Options for handling these melters include (1) locating a facility to conduct the size-reduction, characterization, and containerization as originally planned; (2) long-term storing or disposing of the complete melter assembly; and (3) attempting to refurbish the melter and to reuse the melter assembly.

The focus of this report is to look at methods and issues pertinent to size-reduction and/or melter refurbishment in particular, removing the glass as a part of a refurbishment or to reduce contamination levels (thus allowing for disposal of a greater proportion of the melter as low level waste). 


\section{DESCRIPTION OF MELTERS}

A brief description of the two melters being operated in the United States and the Pamela melter operated in Belgium follows.

\subsection{WVDP}

A Functional and Checkout Testing of Systems (FACTS) program to test new equipment and processes was conducted from 1984 to 1989 . While a detailed description of the FACTS testing can be found in ref. 1 and the disassembly results in ref. 2, only a brief summary relevant to the purposes of this report are included here.

In the FACTS testing, a slurry-fed ceramic melter (SFCM), similar to the one currently in operation, was used to make $150,000 \mathrm{~kg}$ of glass using materials to simulate radioactive waste. The SFCM, which was used during the FACTS testing, (Fig. 1), is shaped like an inverted prism with the vessel walls sloped inward toward the bottom. The melter has three electrodes: two in the sides of the vessel and one in the floor at the base of the inverted prism. Normal glass inventory during operations was $0.86 \mathrm{~m}^{3}$. Weight, while full of glass, was about $47,200 \mathrm{~kg}$. The shape of the melter was selected in part to minimize inventory in the melter should the system fail. The melter is encased inside a watercooled-jacket. Interior surfaces of the box are made from Inconel ${ }^{\circledR} 690$ for corrosion resistance. The exterior of the water-cooled-jacked is made from type 304 stainless steel.

Drainage of the molten glass was conducted using an "airlift" mechanism, which introduced air bubbles into the discharge passage to raise the level of the melt, thus causing it to flow out in an intermittent rather than continuous flow. Complete draining was performed twice using an evacuated canister suction technique following the "airlift" method. Both times, about $95 \%$ of the glass was removed from the melter.

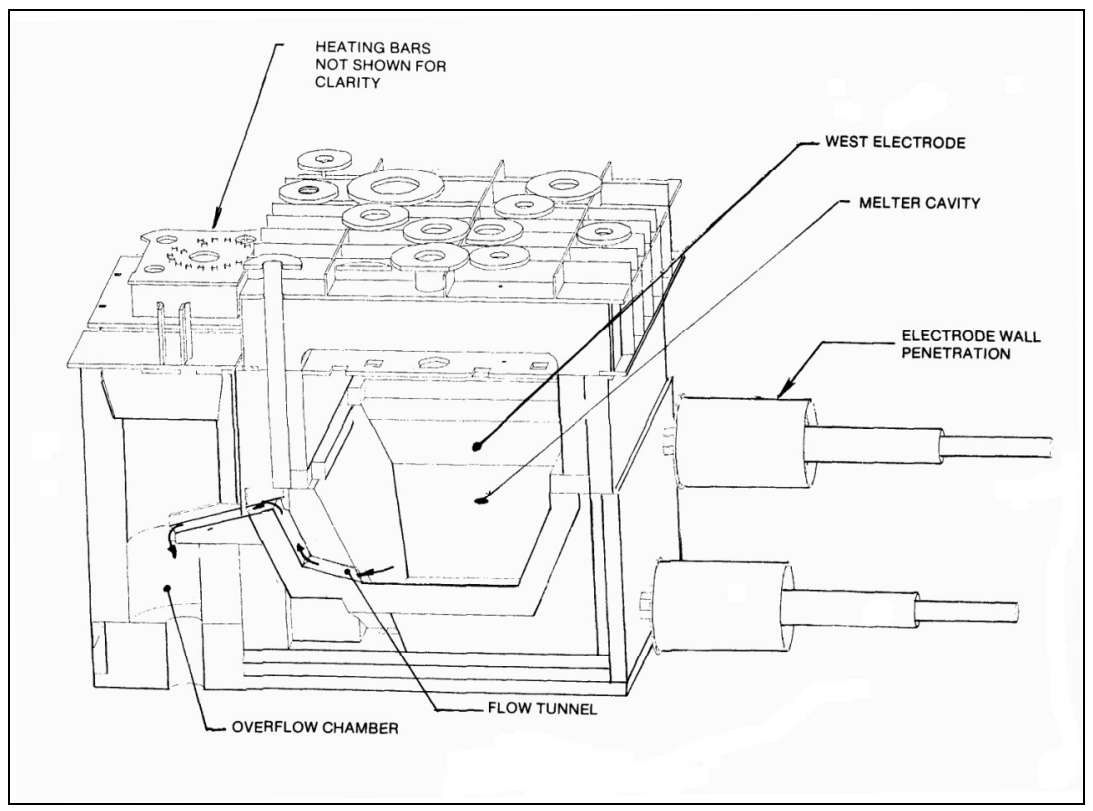

Fig. 1. WVDP SFCM Section (ref. 3). 
The SFCM used for the HLW processing is similar to the melter used in the FACTS testing. A summary description is provided here, while a more detailed description can be found in ref. 4 . The melter is a $3.05 \times 3.05 \times 3.05 \mathrm{~m}(10 \times 10 \times 10 \mathrm{ft})$ cube and weighs about $48,100 \mathrm{~kg}$. The melter cavity accommodates $0.86 \mathrm{~m}^{3}$ of molten glass during normal operations. The melter is supported by a painted carbon-steel structure, which is bolted to the floor. This melter has been processing HLW since 1996 and more than $95 \%$ of the HLW has been vitrified.

\subsection{DEFENSE WASTE PROCESSING FACILITY (DWPF)}

The DWPF is located at the DOE's SRS and has been processing HLW since 1996. Before that, a 1:10 pilot-scale melter, the Integrated DWPF Melter System (IDMS) melter (Fig. 2), was operated continuously for 7 years at $1150^{\circ} \mathrm{C}$ (ref. 5). The IDMS processed simulated waste glasses from 1988 until it was shut down in 1995 so that it could be inspected to form a baseline for determining the requirements for future inspections of the DWPF melter and off-gas piping. Upon completion of the IDMS operations, the melter was inspected, and data were gathered on system wear and the composition of deposits remaining in the melter.

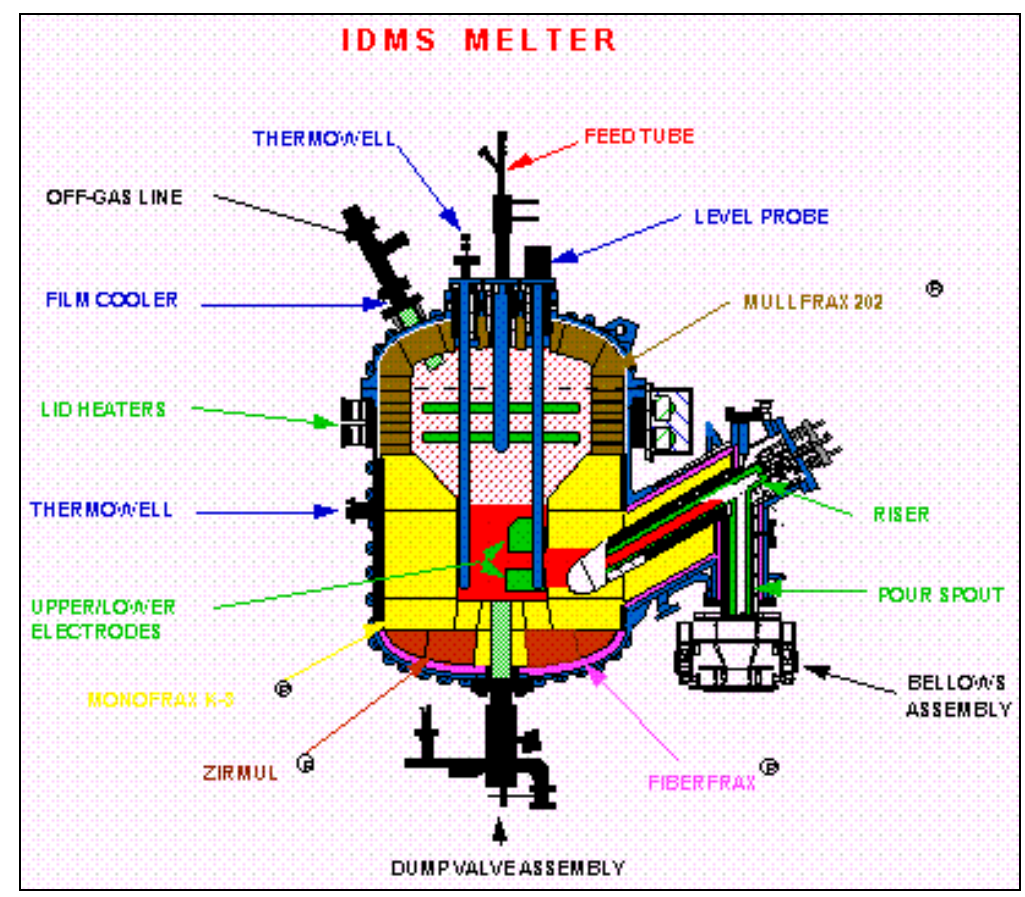

Fig. 2. IDMS melter section (ref. 5).

The DWPF melter (Figs. 3-4) is a water-jacketed, refractory-lined, stainless steel vessel, which is designed for waste vitrification at rates of $100 \mathrm{~kg}$ of glass per hour. ${ }^{6}$ Two pairs of submersed electrodes are used to pass current through the glass, thus using the electrical resistance of the glass to generate the required heat. In addition, there are Inconel dome heaters (Fig. 4). The size of the melter and the quantity of materials that have to be dealt with in a deactivation and decommissioning (D\&D) operation are quite large. Table 1 lists the components that make up the melter and their weight. The DWPF melter weighs about $40 \%$ more than does the WVDP's SFCM. In addition, the stainless steel frame structure, which is composed primarily of 3/8-in. (9.53-mm) stainless steel tubing, weighs an additional 77,000 kg. The volume of drainable glass is $2.22 \mathrm{~m}^{3}$ before any wall erosion is taken into account. 
Table 1. DWPF melter components

\begin{tabular}{|lr|}
\hline \multicolumn{1}{|c}{ Component } & Weight $(\mathrm{kg})$ \\
\hline \hline Vessel (stainless steel) & 17,600 \\
\hline Frame(stainless steel) & 12,900 \\
\hline Refractory & 25,230 \\
\hline Piping & 9,790 \\
\hline Components & 1,200 \\
\hline Nozzle mounting materials & 930 \\
\hline Wiring & 150 \\
\hline Total & 67,800 \\
\hline
\end{tabular}

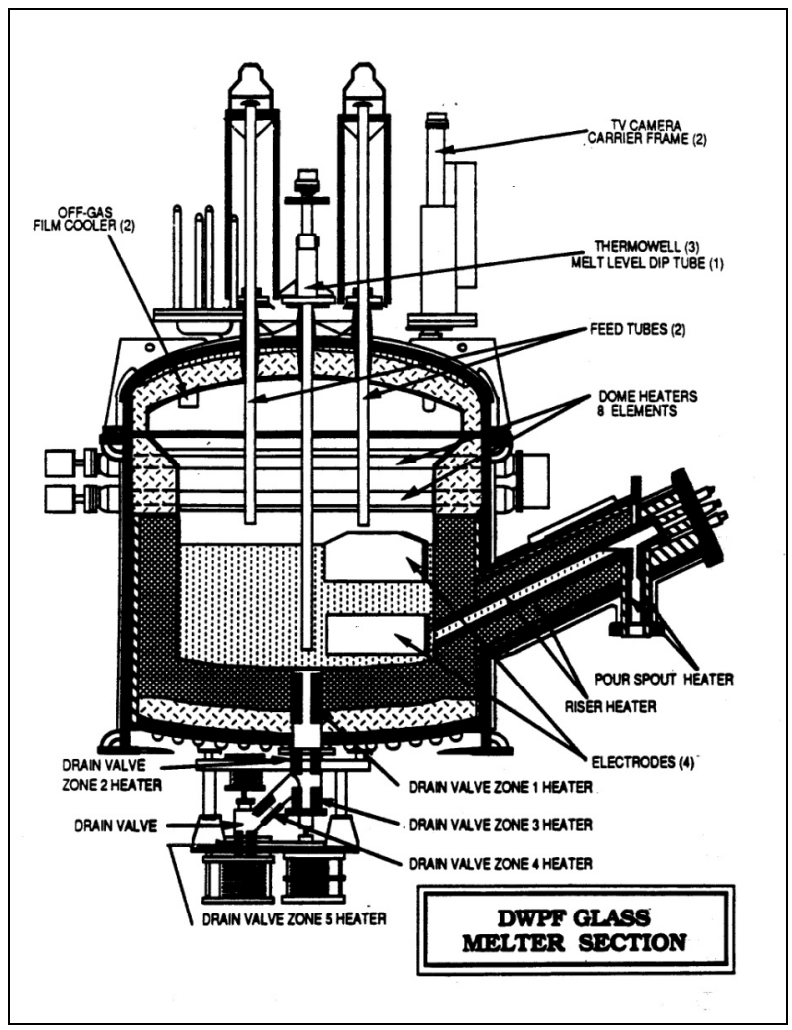

Fig. 3. DWPF melter section. 

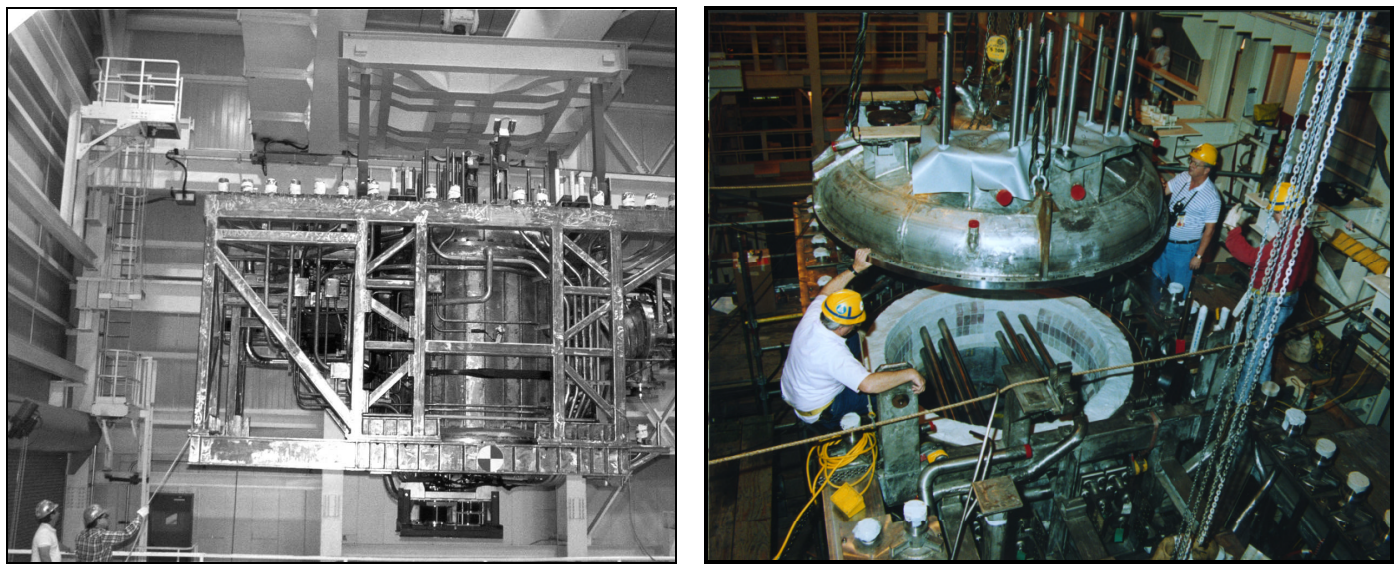

Fig. 4. DWPF melter assembly and installation.

\subsection{PAMELA}

The Pamela Plant (Fig. 5) in Dessel, Belgium, was used to vitrify high-level liquid reprocessing waste by using a ceramic melter. Initial vitrification operations were conducted from 1985 to 1991, with a second vitrification program to start in 1999 , following D\&D of the hardware components from the initial operations.

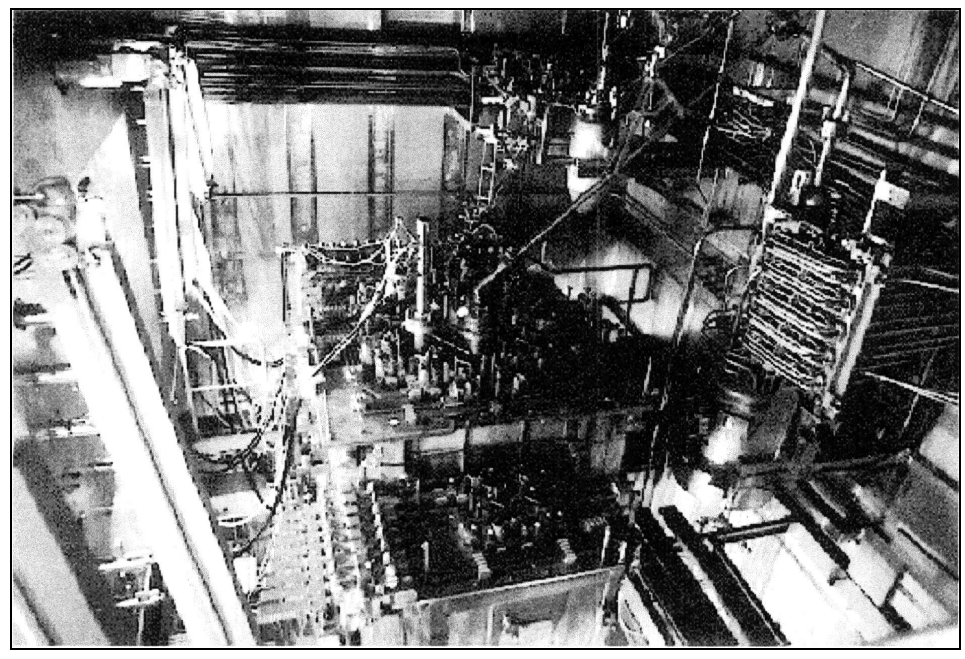

Fig. 5. Pamela vitrification plant (ref. 7).

During the initial vitrification operations, some $900 \mathrm{~m}^{3}$ of waste concentrates were processed. In an initial feasibility demonstration, $47.2 \mathrm{~m}^{3}$ of waste concentrates from the reprocessing of power reactor fuels were incorporated into 77.8 metric tons $(\mathrm{t})$ of glass product, containing $7.67 \mathrm{t}$ of waste oxides. ${ }^{7}$ The subsequent operations processed $777 \mathrm{~m}^{3}$ of waste concentrates from the reprocessing of materials testing reactor fuels were incorporated into $411.7 \mathrm{t}$ of glass product, containing $88.94 \mathrm{t}$ of waste oxides. ${ }^{7}$

A cross section of the $2 \times 2 \times 2 \mathrm{~m}$ cube-shaped ceramic melter is shown in Fig. 6 . The total weight of the ceramic melter was $18 \mathrm{t}$, with the refractory bricks (40 to $300 \mathrm{~kg}$ each) weighing $5 \mathrm{t}$, the 
insulation material weighing $7 \mathrm{t}$, and the stainless steel shell ( 3 to $20 \mathrm{~mm}$ thick) and additional equipment accounting for the rest of the weight. ${ }^{7}$ Table 2 lists the basic components and characteristics of the melters.

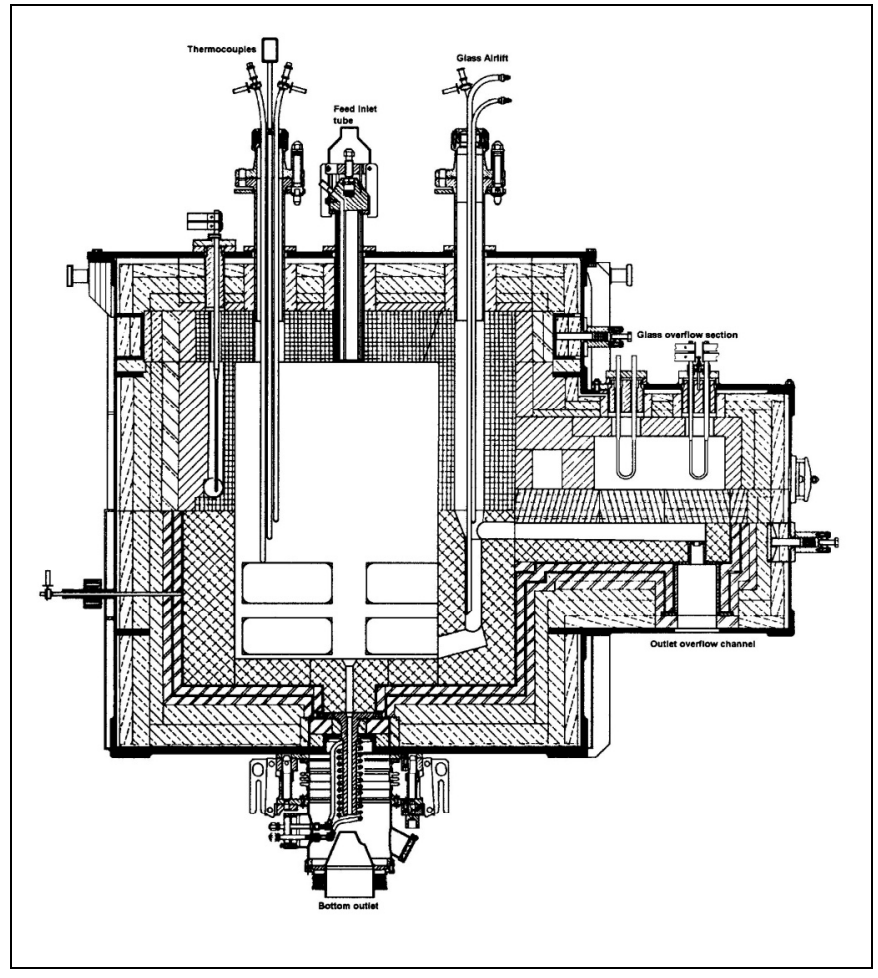

Fig. 6. Cross section of the Pamela melter (ref. 7).

Table 2. Basic melter parameters (ref. 7)

\begin{tabular}{|l|l|}
\hline \multicolumn{1}{|c|}{ Melter Parameter } & \multicolumn{1}{c|}{ Dimensions, Value, or Quantity } \\
\hline \hline External dimensions & $2.0 \times 2.0 \times 2.0 \mathrm{~m}$ \\
\hline Overflow unit dimensions & $0.7 \times 0.9 \times 0.8 \mathrm{~m}$ \\
\hline Refractory material (weight and volume) & 5.2 metric tons $1.4 \mathrm{~m}^{3}$ \\
\hline Insulation material (weight and volume) & 7.3 metric tons $5.4 \mathrm{~m}^{3}$ \\
\hline Built-in metallic components/devices (weight) & 2.0 metric tons \\
\hline Stainless steel containment (weight) & 3.5 metric tons \\
\hline Glass (weight and displacement) & 0.8 metric tons $0.3 \mathrm{~m}^{3}$ \\
\hline Total weight & 18.8 metric tons \\
\hline
\end{tabular}




\section{D\&D EXPERIENCE}

While the DWPF and the WVDP melters have not undergone D\&D at this time, there is some relevant experience that could be beneficial. First, the remaining glass was removed from the IDMS melter before the melter's inspection after the melter was being shutdown in 1995. Second, the Pamela melter underwent D\&D from 1992 through 1994. In addition, remote D\&D operations have been performed on other types of systems. While the equipment being handled certainly varied significantly from the melters that are the subject of this report, there are common issues and concerns, including remote operations in radiation environments and the handling and size-reduction of large components.

\subsection{PAMELA}

From June 1992 through March 1994, four large components of the Pamela vitrification facility were dismantled. The equipment dismantled included one of the two ceramic melters that were used, the vitromet equipment, the wet dust scrubber, and the container lifting and weighing carriage. The details of the D\&D operations are described in Demonie, 1994. A summary of the D\&D operations is included here. $^{7}$

The melter cell facility was used for dismantling because of the remote access already incorporated into the cell design. The cell includes three $(1.0$ by $0.8-\mathrm{m})$ lead-glass windows at ground level with master-slave manipulator pairs at each window. Three additional identical windows are located at a second level, $4 \mathrm{~m}$ higher, from which 2 are equipped with master-slave manipulator pairs. There is also one heavy-duty, mast-mounted manipulator and a 2-t overhead crane, which is located in the melter cell. A schematic of the cell is shown in Fig 7.

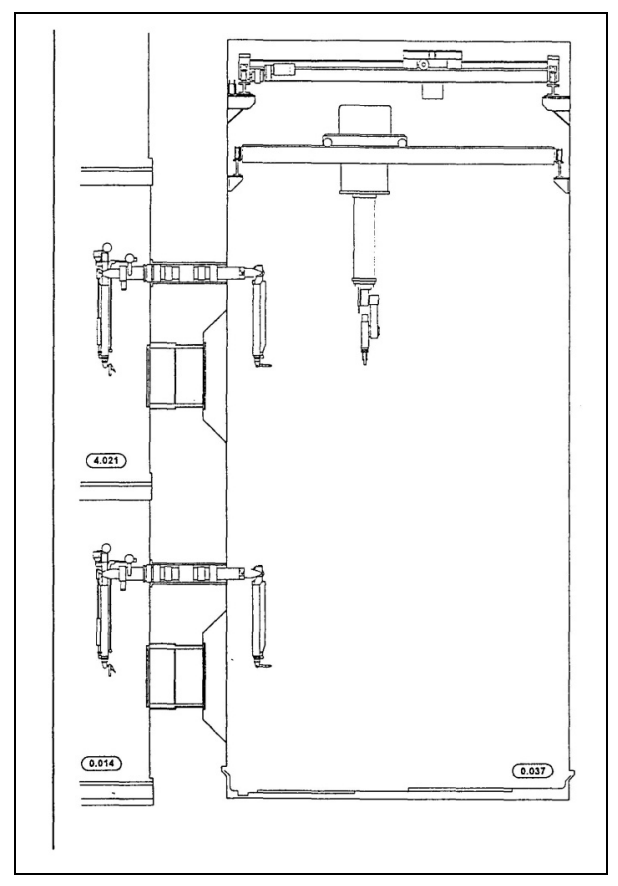

Fig. 7. Melter cell schematic (ref. 7). 
The melter and portions of the vitromet unit were size reduced in the melter cell facility before they were transported to the dismantling cell for packaging. Table 3 lists the dismantling sequence for the melter. The wet dust scrubber and the container lifting and weighing carriage were transferred as one piece prior to size reduction in the dismantling cell.

Table 3. Melter dismantling sequence

\begin{tabular}{|ll|}
\hline \multicolumn{1}{|c|}{ Melter dismantling steps } \\
\hline \hline 1. & $\begin{array}{l}\text { Removal of all external and built-in devices, including thermocouples, bottom } \\
\text { outlet, electrical supply bars, piping, etc. }\end{array}$ \\
\hline 2. & $\begin{array}{l}\text { Removal of melter stainless steel lid, insulation and refractory material from } \\
\text { glass-bath ceiling, and overflow system. Transport of all dismantled parts to } \\
\text { dismantling cell }\end{array}$ \\
\hline 3. & Cutting up stainless steel containment of overflow system \\
\hline 4. & Removal of insulation and refractory material from the melter walls \\
\hline 5. & Removal of insulation and refractory material from the melter floor \\
\hline 6. & $\begin{array}{l}\text { Cutting up remaining containment and transport to dismantling cell for } \\
\text { conditioning }\end{array}$ \\
\hline
\end{tabular}

The dismantling operations were conducted using the through-the-wall manipulator systems and the mast-mounted manipulator. Traditional hand-held tools were modified and adapted for remote operations. Tools consisted of grinding discs, impact wrenches, hydraulic jacks, hammer drills, vacuum cleaners, and grippers. The existing ventilation system precluded the use of plasma torches for cutting large metal structures. Diamond-tipped blades were initially used for cutting, but grinding discs were also tried and proved to be more efficient cutting stainless steel plates. Table 4 shows the approximate cutting rates for the blades and grinding discs.

Table 4. Cutting rates for stainless steel

\begin{tabular}{|lcc|}
\hline \multicolumn{1}{|c}{ Tool } & Thickness $(\mathrm{mm})$ & Rate $(\mathrm{mm} / \mathrm{min})$ \\
\hline \hline Diamond blade & $3-8$ & $7-11$ \\
\hline Grinding disc & 3 & $700-850$ \\
\hline Grinding disc & 5 & $350-450$ \\
\hline Grinding disc & 10 & $180-230$ \\
\hline
\end{tabular}

The resulting waste was segregated based on activity level into low-and medium-level wastes. Medium level waste was cut up and placed in 125-L drums and then each drum was filled with cement. These drums were then placed in 200-L drums, which were also filled with cement before they were sealed with a double-lid system.

The key lessons learned from the dismantlement of the melter and additional equipment are summarized in Table 5. 


\section{Table 5. Lessons learned from dismantling of Pamela melter}

\begin{tabular}{|ll|}
\hline 1. & Dismantling requirements must be taken into account at design phase of plant. \\
\hline 2. & Access to and visual control in shielded cells must be easy. \\
\hline 3. & Manipulators must allow for operation of different tooling. \\
\hline 4. & Ventilation should not preclude the use of plasma torches. \\
\hline 5. & $\begin{array}{l}\text { Larger drums should be used for packaging to reduce time-spent size reducing } \\
\text { waste. }\end{array}$ \\
\hline 6. & $\begin{array}{l}\text { Personnel retrained for dismantling must be experienced remote manipulator } \\
\text { operators. }\end{array}$ \\
\hline
\end{tabular}

\subsection{IDMS}

As stated previously, the IDMS was shut down and inspected to gather data relevant to the DWPF melter - specifically to help in determining appropriate inspection schedules and to minimize the number of scheduled inspections. While the IDMS did not undergo D\&D types of activities, some of the experience gained from the inspection of the IDMS is relevant to future melter D\&D activities, including the following activities ${ }^{5}$ :

- Attempts to drain glass through the drain valve were unsuccessful because of an inoperative drain valve heater.

- A high vacuum pour was performed to try to remove as much glass as possible. About $30 \mathrm{~cm}$ (12 in) of glass remained in the melter after the pour.

- The glass remaining in the bottom of the melter was core-drilled. A total of 38 samples were removed for analysis.

- The remaining glass was removed from the melter by beadblasting (like sandblasting, but with larger particles that do not damage the refractory) and chipping.

- Remaining "blobs" of glass were then easily removed from the refractory.

- All components in the vapor space region had yellow deposits. The melter lid, which also had the deposits prior to cleaning, was beadblasted to remove them.

- The riser and pour spout were plugged after draining and were unplugged by drilling and beadblasting.

- The feed tube was also plugged.

\subsection{RELEVANT DOE D\&D ACTIVITIES}

A number of DOE sponsored development and demonstrations have been conducted, largely through the D\&D Focus Area. Those with aspects most relevant to dismantling of melters will be discussed.

\subsubsection{Chicago-Pile No. 5 (CP-5) D\&D}

The CP-5 research reactor, which is located at Argonne National laboratory (ANL), was a heavywater-moderated and -cooled, highly enriched, uranium-fueled reactor, which was designed to supply neutrons for research. An artist's rendering, which depicts a cutaway of the reactor block, is shown in Fig. 8. The reactor vessel itself was $1.8-\mathrm{m}(6-\mathrm{ft})$ in diameter and 3.0-m (10-ft) long. The reactor had a power rating of $5 \mathrm{MW}$ and was operated for 25 years until its final shutdown in 1979. Years of operation 
produced activation and contamination that are typical of many nuclear facilities within the DOE complex. The CP-5 remote tasks included cutting and dismantling the aluminum reactor tank, disassembling and removing the array of graphite blocks, removing boral and lead sheathing and lead bricks, and transferring these materials to a staging area for packaging. The Dual Arm Work Platform (DAWP) (Fig. 9), which was developed by Oak Ridge National Laboratory (ORNL), was used by the CP5 operations staff to remove $27,000 \mathrm{~kg}(60,000 \mathrm{lb})$ of graphite blocks; $773 \mathrm{~kg}(1700 \mathrm{lb})$ of aluminum reactor vessel, piping and support bracing; $909 \mathrm{~kg}$ (2000 lb) of steel; $636 \mathrm{~kg}$ (1400 lb) of lead; and $282 \mathrm{~kg}$ $(620 \mathrm{lb})$ of boral.

The DAWP, which is shown in Fig. 9, had many of the design components of the earlier Dual Arm Work Module (DAWM), however, it was reconfigured for CP-5. ShillingTM T3 manipulators were selected because they were more easily decontaminated than the T2 manipulator. The DAWM style linear and rotary base platform actuators were also reused, except that the Schilling ${ }^{\mathrm{TM}}$ linear actuators extended out from the base perpendicularly, and the rotary joint provided a $90^{\circ}$ change in arm-base orientation from vertical to horizontal. The manipulation and base degree of freedom (DOFs) were mounted on a structure designed to be crane deployed and left either free swinging or sat down on the reactor block during task execution.

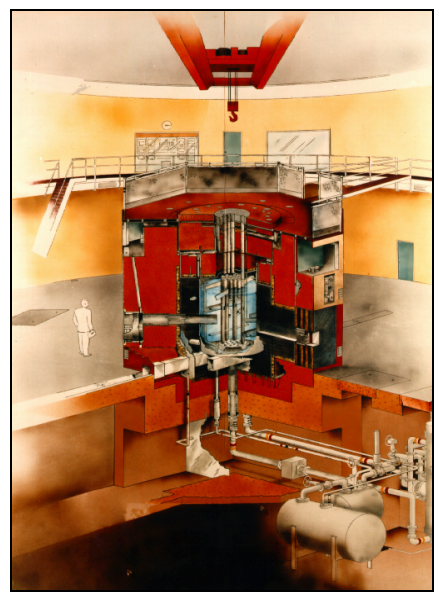

Fig. 8. Schematic of the CP-5 research reactor.

Two general comments are worth discussing. ${ }^{8}$ First, operator skill was an issue. The site required that existing union personnel be used to operate the system, despite the fact that none had any remote-operating experience. While the task was completed successfully, past lessons learned on the need for experienced remote operators was clearly reinforced.

The second concerns reliability. The controls and mechanical hardware were generally reliable. The single exception was a recurring failure of the Schilling manipulator elbow joints on both manipulators. Although the cause was never firmly established, it could have been related either to the use of HoughtoSafe ${ }^{\mathrm{TM}}$ water-glycol hydraulic fluid or to some peculiar stresses placed on the Schilling manipulators because of the configuration of the manipulators on the DAWP base. ORNL has since used Shell Tellus ${ }^{\mathrm{TM}}$ mineral-oil-based hydraulic fluid in its development systems. Other failures included cameras and camera lenses, but these were caused almost exclusively by impact with the environment during emplacement of the DAWP or from the manipulators. Because this type of failure was expected, relatively inexpensive dome cameras were selected. 


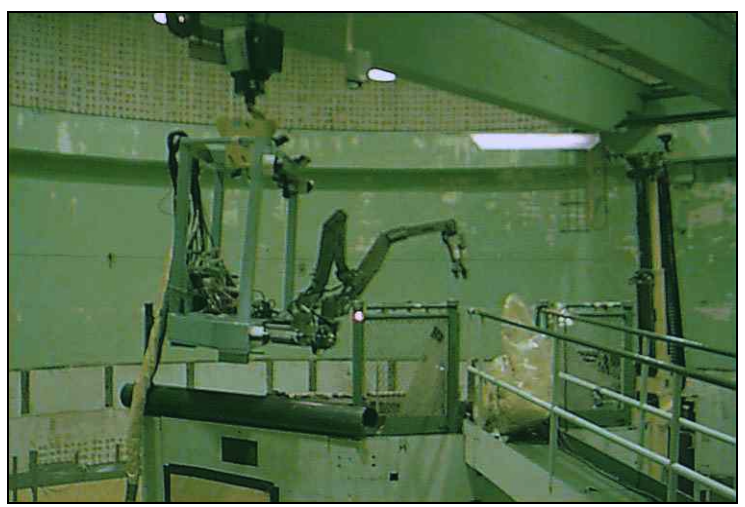

Fig. 9. DAWP working above the CP-5 research reactor.

\subsubsection{Size-Reduction of the Tokamak Fusion Test Reactor Vacuum Vessel}

The D\&D Focus Area supported a demonstration of diamond wire cutting of a Tokamak Fusion Test Reactor (TFTR) surrogate section to evaluate optimum conditions for eventual size-reduction of the TFTR. The demonstration was conducted at the Princeton Plasma Physics Laboratory (PPPL) in the late summer of 1999 to determine if diamond wire cutting was a viable technology for size-reducing the TFTR without workers in close proximity. The demonstration was conducted using a diamond wire cutting system from Bluegrass Concrete Cutting, Inc. The test setup is shown in Fig. 10.

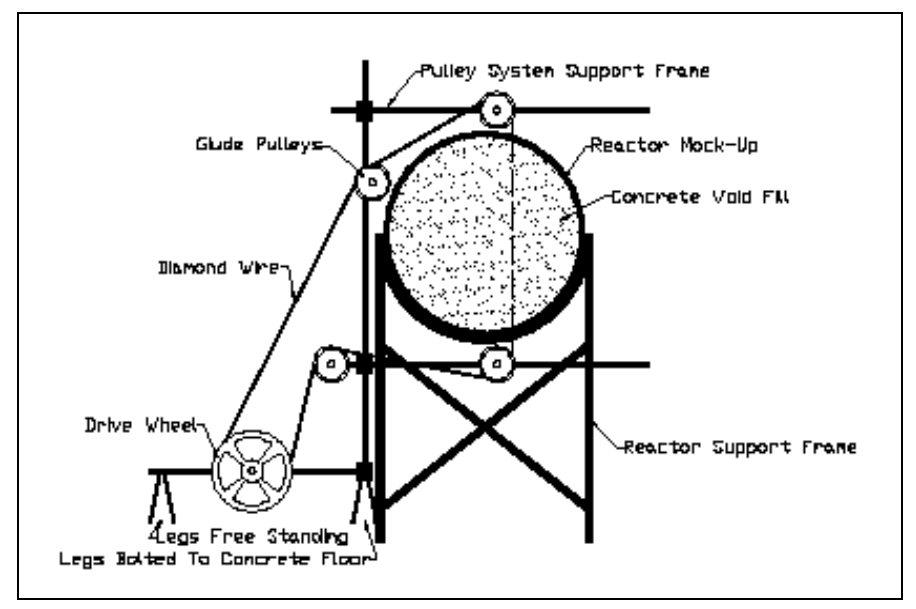

Fig. 10. TFTR diamond wire cutting setup (ref. 9).

The process of diamond wire cutting has been developed and deployed for size-reduction of large concrete structures, which typically contain steel reinforcement. The use of this technology for sizereduction of large metal structures, such as the TFTR vacuum vessel (Fig. 11), which was made of multiple layers of type 304 stainless steel and Inconel, is facilitated by the use of void filler material. The fillers (Fig. 12) are used to maintain the structural integrity of the vessel during cutting, clean the diamond bits as they cut, limit the dispersal of contaminants, and provide shielding. Three void space fillers were tested, Rheocell-15 (foamed, low-density concrete), mortar, and Perma-Fill foam (aqueous based), as well as three different cooling agents (water, air, and liquid nitrogen). 


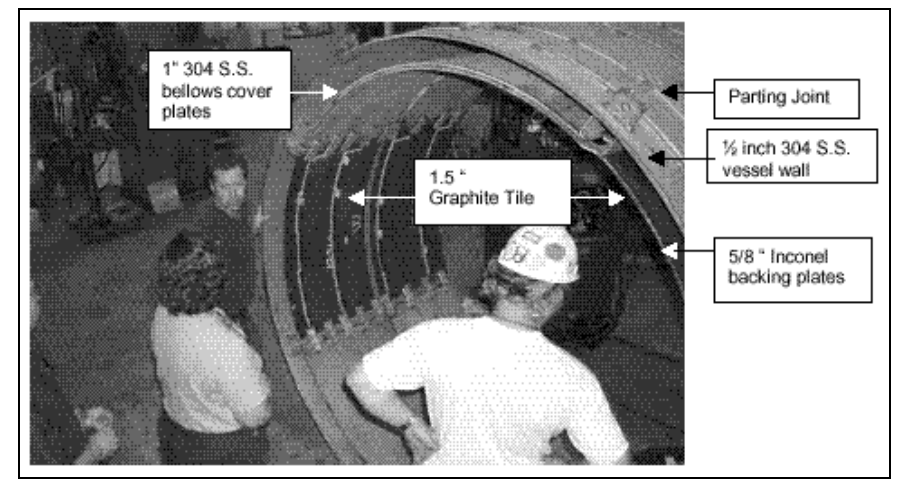

Fig. 11. TFTR vacuum vessel (ref. 9).

The system consists of a diamond wire (made from wire rope, springs, and synthetic diamonds bonded to a steel bead) and a hydraulic or electric drive system (drive wheel, idler pulleys, support structure, and a stroke cylinder to maintain tension). The drive wheel rotates, pulling the wire through the cut area and the cooling medium, which is used to both clean and cool the wire.
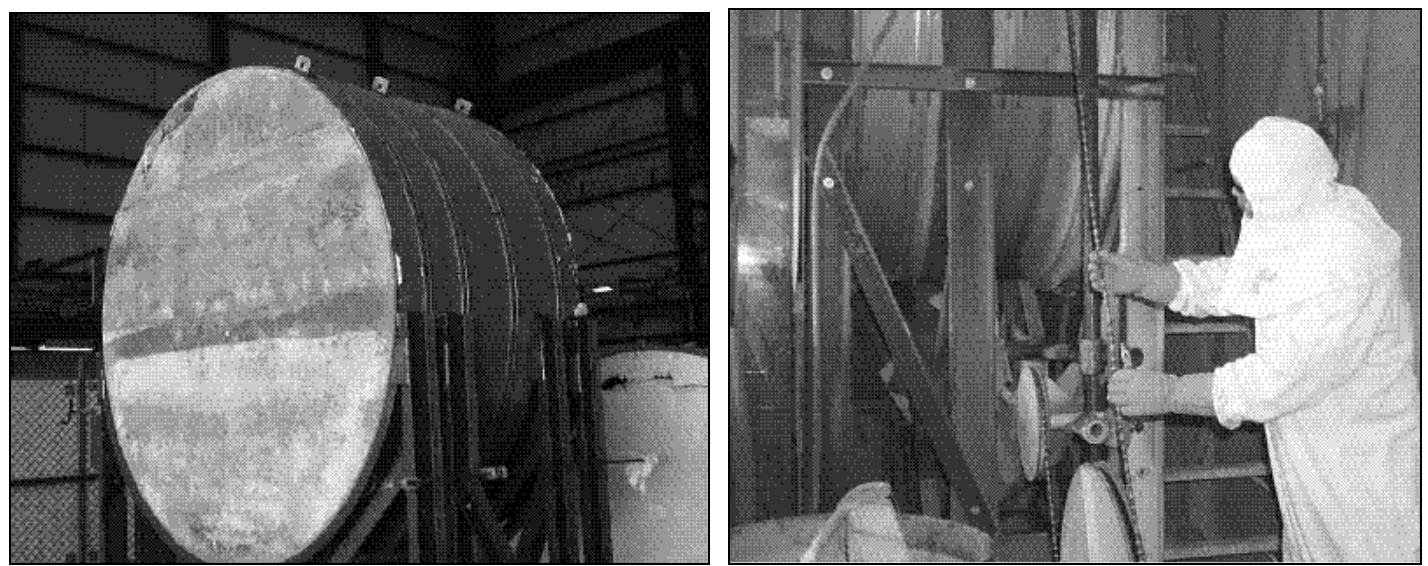

Fig. 12. Filled vacuum vessel and wire and pulleys setup (ref. 9).

The results of the testing were favorable with these notable results?

- Successfully demonstrated cutting of large metal structures consisting of metals of varying hardness with a concrete matrix.

- Rheocell-15 provides a number of advantages, including:

- 3-5 times lighter than concrete, reducing shipping costs.

- Flows similar to water, filling voids to provide cutting stability when set.

- Reduced friction vs. conventional concrete.

- Provides shielding from gamma radiation (40-40\% reduction).

- Places segment in proper disposal form.

- Improves worker safety by allowing remote cutting.

- Water and liquid nitrogen cooling are both viable.

- Bead wear reduces cutting diameter, increasing difficulty in introducing replacement wires. Reducing tension to allow "wallowing" could help this problem. 


\subsubsection{Modified Brokk Demolition Machine with Remote Console}

An integrated system, referred to as the Modified Brokk Demolition Machine with Remote Console, was deployed during D\&D activities at the Idaho National Environmental and Engineering Laboratory (INEEL) South Tank Farm (STF) in January 2000. Specifically, the system was used by an operator to remotely remove, size-reduce, and stage overhead piping and facility equipment located in the basement of the STF. Before the Modified Brokk Demolition Machine with Remote Console was used, this work was done with the operator in the area in direct line-of-sight of the operation. The system consisted of the ORNL compact remote console (CRC) integrated with the commercially available Brokk 250 , to provide a functional, relatively low-cost remote D\&D capability.

The Brokk 250 consists of a revolving table, which is capable of continuous rotation and mounted on a tractor-like base. Solid rubber wheels mobilize the equipment, and hydraulic outriggers extend beyond the tires to add stability during operation. The unit requires a $480-\mathrm{V}$ ac, $50-\mathrm{A}$ circuit for its power source. The Brokk can be operated from 400-ft away using either a tethered portable controller or a wireless radio frequency (rf) portable controller. In the baseline mode, the Brokk is controlled by an operator standing in close proximity to the machine with line-of-sight vision of the work site. Figure 13 shows the Brokk BM 250 being used for D\&D activities while using the wireless rf controller.

Following are some of the physical characteristics of the Brokk 250:

$\begin{array}{ll}\text { Weight: } & 6,750 \mathrm{lb} . \text { without attachments } \\ \text { Minimum height: } & 3.61 \mathrm{~m} \\ \text { Minimum width: } & 1.50 \mathrm{~m} \\ \text { Minimum length: } & 1.19 \mathrm{~m} . \\ \text { Operating width: } & 2.46 \mathrm{~m} \\ \text { Maximum attachment weight: } & 299 \mathrm{~kg} \\ \text { Hydraulic breaker energy per blow: } & 1356 \mathrm{~nm}\end{array}$

Various tool head attachments are available for this system, including a hydraulic hammer, an excavating bucket, a concrete crusher, and a La Bounty Shear, which is shown in Fig. 13. The La Bounty Shear was the primary tool head used for this demonstration and is capable of cutting rebar, pipe, and other metal, and the shear weighs about $600 \mathrm{lb}$. A field demonstration of a Brokk BM 150 was conducted in 1997-1998 at the CP-5 Research Reactor Large-Scale Demonstration Project to compare the Brokk BM 150 with manual jackhammer methods. ${ }^{10}$

In order to perform D\&D activities from a truly remote non-line-of-sight location, the Brokk 250 was retrofitted with two image-stabilized cameras, which were mounted in a pan-and-tilt aluminum enclosure. The image-stabilized DRaySEE ${ }^{\mathrm{TM}}$ camera system, which was used, is commercially available from RVision, Inc., and it produces 350 lines NTSC video, pans $360^{\circ}$, tilts $110^{\circ}$, and provides 24 times image magnification (12X optical). The $12-\mathrm{V}$ dc system requires separate power for the pan-and-tilt functions and a serial interface to control camera zoom features. These two cameras were mounted on two actuated arms, which are located on the cover of the Brokk 250. The actuated arm system allows the cameras to be positioned in the optimal viewing position during work activities and to be retracted while the Brokk is being moved throughout the remote area. By mounting the camera and actuator system on the cover, the Brokk 250 can easily be changed from remote-camera ready to original equipment by simply interchanging covers. 
The purpose of the CRC is to condense a typical multi-monitor, multi-rack large operator control console into a single, and easy-to-relocate ergonomic station. The CRC measures $76.2 \times 154.9 \times 193.0$ $\mathrm{cm}$ and consists of a 4-panel video array, which is mounted on a mast in front of an ergonomic chair. These are subsequently mounted on a base, which serves as an enclosure for associated power, video switchers, and control and fiber-optic electronics. Also mounted on a swivel arm on the CRC is a control computer with a touch-screen, which serves as an intuitive graphical user interface to the Modified Brokk Demolition Machine. Figure 14 shows the CRC with an integrated portable Brokk 250 controller and an inside view of the base enclosure. ${ }^{11}$

The benefits from this Modified Brokk Demolition Machine with Remote Console include:

- operable by remote control, allowing the operator to be positioned at a safe distance from high radiation areas, falling debris, cold and hot temperatures, and other environmental concerns;

- working time less than half that of most manual tools, significantly reducing cost, schedule, and worker radiation exposure;

- powered by a 480-V ac, 3-phase motor, eliminating problems of exhaust fumes in containment areas;

- useful for a wide range of tasks in various work conditions from breaking, removing, and loading concrete debris to removing radioactive waste from high radiation areas; urable - operated on double 10-h shifts for weeks without failure (expected useful life is about 10 years).

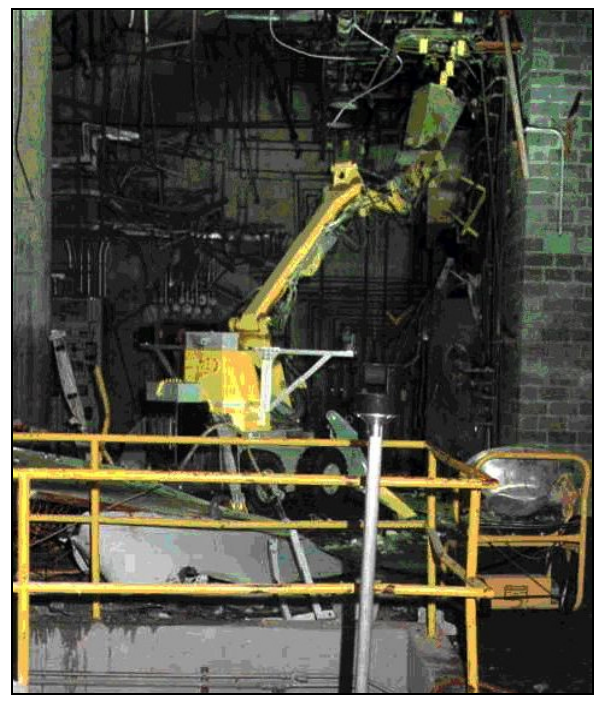

Fig. 13. Modified Brokk performing facility D\&D task (ref. 12). 


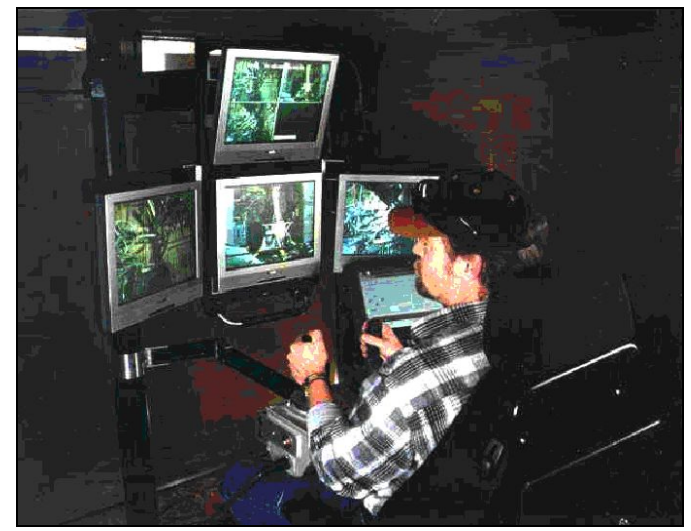

Fig. 14. Compact console controlling the modified Brokk (ref. 12).

\subsubsection{Other D\&D Focus Area Supported Demonstrations}

The D\&D Focus Area has supported additional demonstrations that are of varying relevancy to melter dismantlement. The DAWP demonstration at ANL, the modified Brokk demonstration at INEEL, and the diamond wire cutting demonstration at PPPL have all been discussed previously. The D\&D Focus Area has also supported demonstrations of the oxy-gasoline torch ${ }^{13}$, a self-contained pipe-cutting shear, ${ }^{14}$ and a size-reduction machine. ${ }^{15}$ The pipe-cutting shear that was tested is applicable to pipes up to 2.5 in. in diameter, and the size-reduction machine is currently a manually operated positioning mechanism for a shear - head, with advantages for overhead operations. The one potential advantage of most relevance to dismantlement of large melter systems is the oxy-gasoline torch.

The oxy-gasoline torch was demonstrated at DOE's Fernald Environmental Management Project (FEMP), and its performance was compared to that of an oxy-acetylene torch. The oxy-gasoline torch relies on $100 \%$ oxidation to cut through metal rather than a combination of oxidation and melting, which other oxy-fuel torches rely on. ${ }^{13}$ The $100 \%$ oxidation allows for easier cutting of thicker steels, with minimal kerf, and reduced likelihood of tip clogging. The key results of the demonstration $\operatorname{are}^{13}$ :

- The oxy-gasoline torch cut all thicknesses of steel between 0.5 and $4.5 \mathrm{in}$. faster than the oxy-acetylene torch; three times as fast at 4.5 in. thick.

- The oxy-gasoline torch produces $\mathrm{CO}_{2}$ and water during cutting. The oxy-acetylene torch also produces $\mathrm{CO}$ and $\mathrm{C}$, which is emitted as a black, sooty smoke.

- The oxy-gasoline torch produces a granular slag, which has a lower thermal capacity than does molten steel, reducing sparking and popping and the risk of fire, as compared to the oxy-acetylene torch.

- The oxy-gasoline torch is more portable. Thirty pounds of gasoline are required for cutting the same amount of steel as $250 \mathrm{lbs}$ of acetylene.

- The liquid gasoline is safer to handle than is pressurized acetylene. 


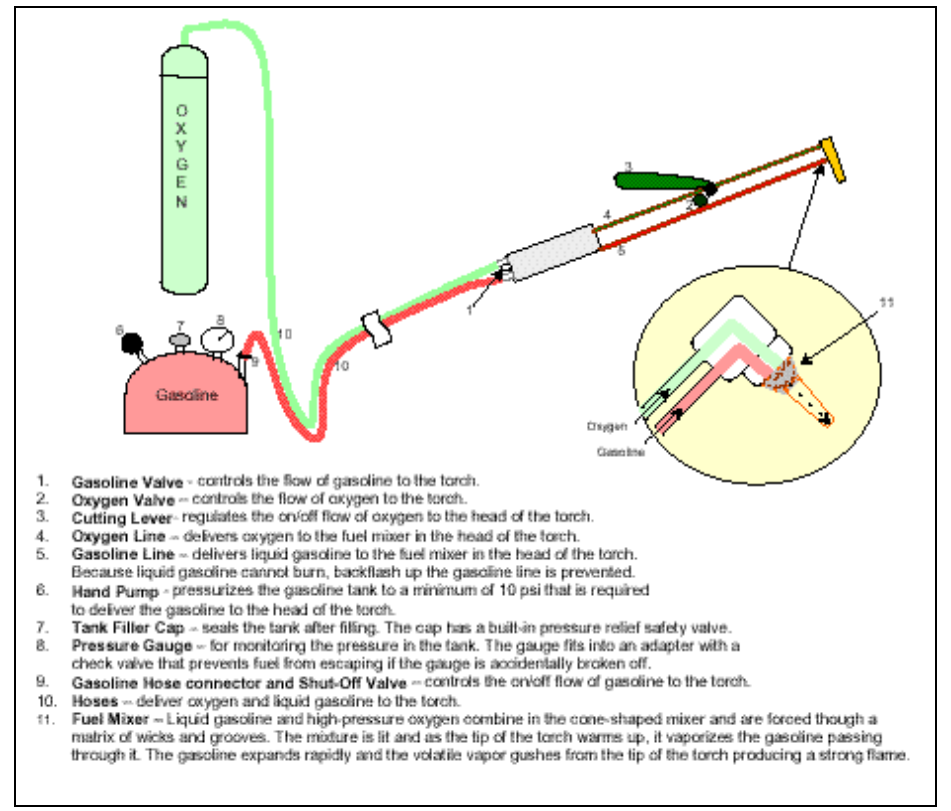

Fig. 15. Petrogen oxy-gasoline torch schematic (ref. 13). 


\section{COMMERCIAL CAPABILITIES}

There are commercial suppliers of relevant hardware and services. These can take the forms of components that can be made into remote systems to perform required tasks to complete systems and services based on tethered operation. Keibler-Thompson ${ }^{\mathrm{TM}}$ of New Kensington, Pennsylvania, provides both services and hardware systems targeted at foundries, metal producers (including steel mills), cement plants, glass melters, and others industries. Keibler-Thompson ${ }^{\mathrm{TM}}$ features special remote-controlled equipment and skilled operators. Other vendors, such as Brokk AB and RedZone, provide relevant hardware components and systems.

\subsection{KEIBLER-THOMPSON ${ }^{\mathrm{TM}}$}

Keibler-Thompson ${ }^{\mathrm{TM}}$ (www.keibler-thompson.com) manufactures a wide range of remotely controlled heavy-duty, industrial equipment for refractory tear-out, descaling, and other applications. It also provides a variety of attachments for most of its machine models. These include hydraulic and pneumatic hammers, buckets, shears, grapples, refractory profiling grinders, tap-hole reamers, and other custom-designed tooling.

Keibler-Thompson ${ }^{\mathrm{TM}}$ equipment features telescoping booms, which are equipped with pneumatic or hydraulic hammers, which allow full reach for deslagging, descaling or refractory tear-out. Some models are designed with their own stabilizing outriggers to allow them to clamp onto the top or inside furnaces or tanks.

Shown in Fig. 16 are representative Keibler-Thompson systems. (Note that the systems are remotely controlled using a hand-held pendant.) Systems that are floor mounted, vehicle mounted, and mounted on top of the targeted system are shown in the figure.

\subsection{BROKK}

Brokk is a remote-controlled, electrically driven demolition machine, which is manufactured by Brokk AB, a fully owned subsidiary of Sorb Industri AB of Skellefteå, Sweden. Brokks machines are available in a variety of models and sizes and can be outfitted with different tooling, including shears and jackhammers, in similar fashion to that of the remotely controlled mobile equipment, which is offered by Keibler-Thompson ${ }^{\mathrm{TM}}$. Figure 17 shows a Brokk 250, which is outfitted with a shear and is performing D\&D activities. 

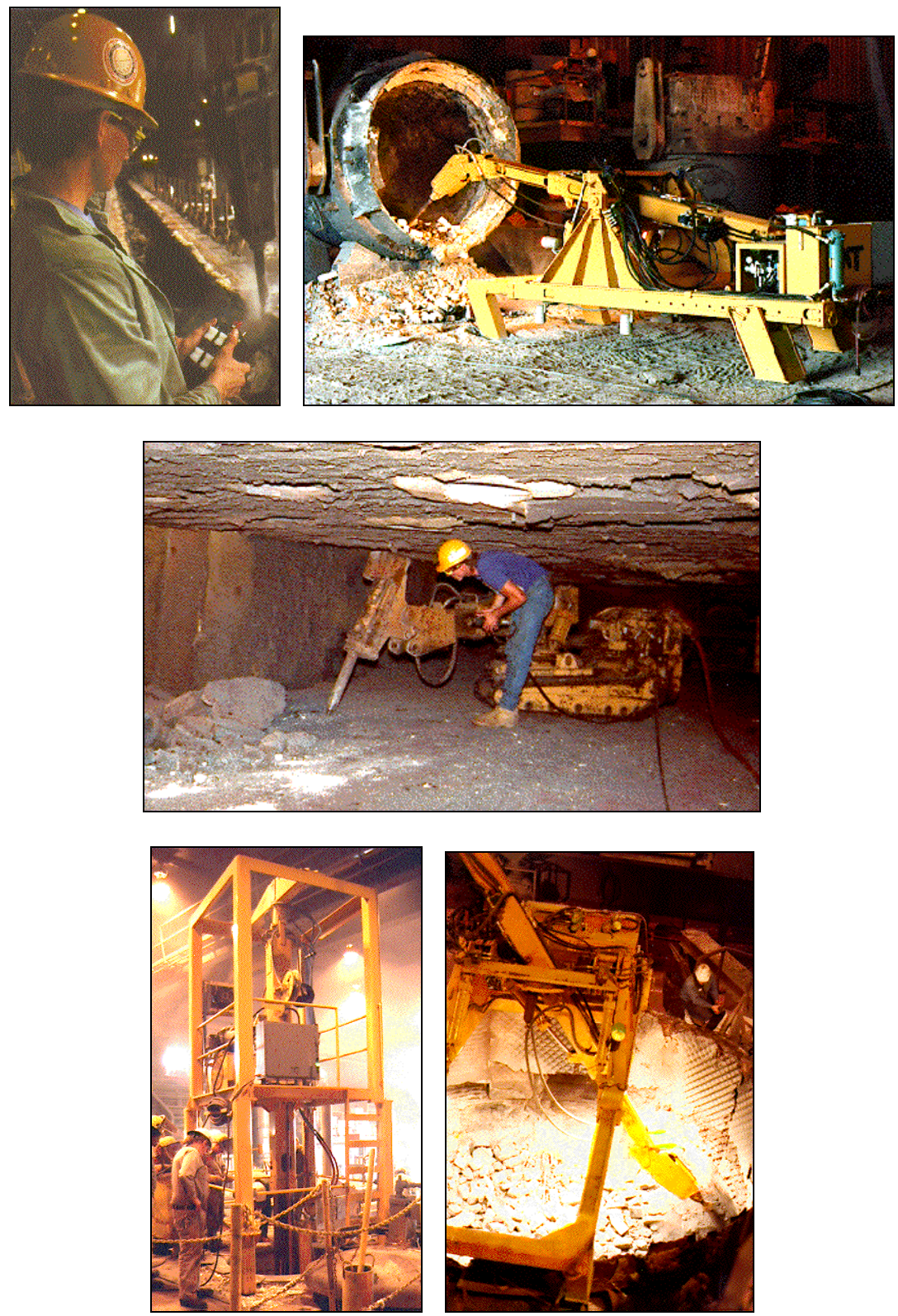

Fig. 16. Keibler-Thompson remote systems. 


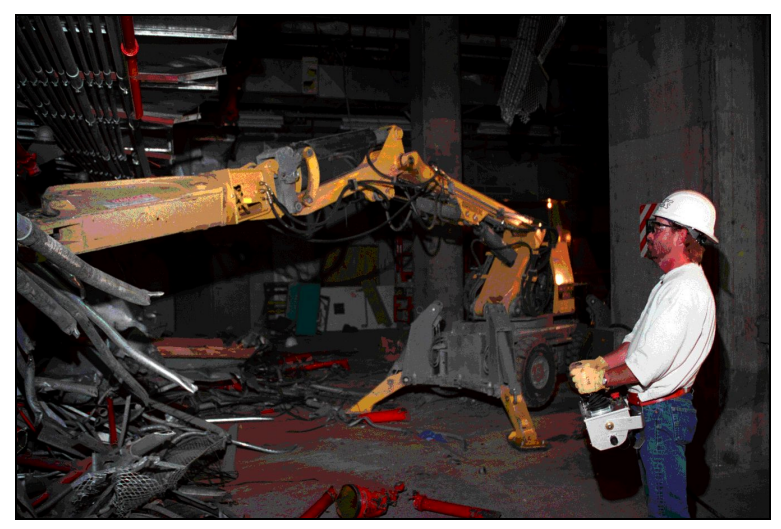

Fig. 17. Brokk remote-controlled system performing D\&D tasks.

\subsection{BLUEGRASS CONCRETE CUTTING, INC.}

Bluegrass Concrete Cutting, Inc. is a specialized cutting and demolition contractor. Bluegrass provides services including diamond wire sawing of reinforced concrete and metal as described above and electric hydraulic robotic hammers for remote demolition work. Shown in Fig. 18 is a 120-ton condenser, which was split in half for removal at the Arkansas nuclear plant using diamond wire cutting. The cut went through 27,000 Inconel tubes, steel pipes, and steel baggle plates, and the entire cutting process took $12 \mathrm{~h}$. More information on Bluegrass can be obtained from its web page (www.concretecutters.com).

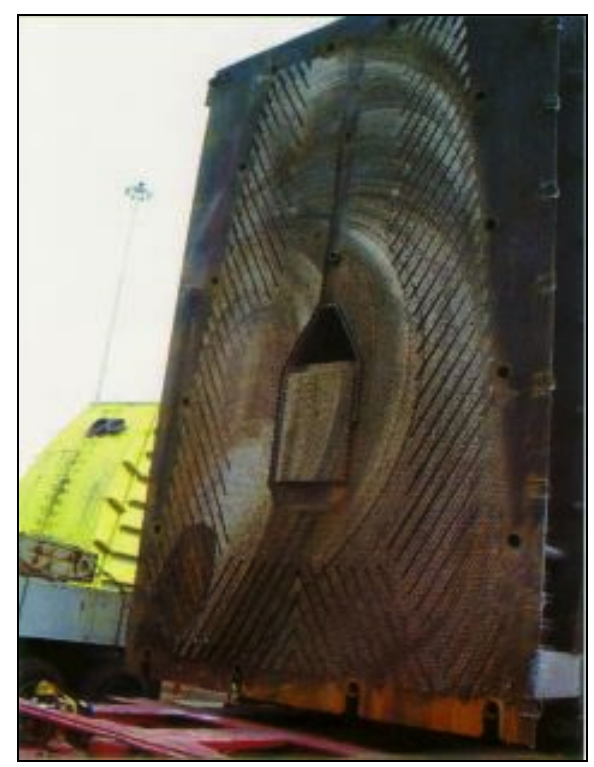

Fig. 18. Condenser cut using diamond wire cutting. 


\section{TOOLING}

One of the primary tasks for size reduction is cutting. Cutting large structural elements remotely significantly increases the difficulty. Additionally, remote routine maintenance of the cutting tool, such as blade replacement, increases the complexity.

ORNL conducted a study of tooling requirements for remote D\&D activities in $1995 .{ }^{16}$ The report was never formally published. An emphasis of that study was remote cutting, which is pertinent to the purposes of this report. The findings and results of that study will be drawn upon in addressing issues relating to cutting here.

\subsection{REMOTE CUTTING}

Cutting tools and processes generally can be categorized based on the method of cutting, namely sawing, shearing, melting/gas jet kerf removal, or ultra-high-pressure fluid impingement. There are multiple approaches to each method, and there are applications where each is more advantageous than the other methods.

Sawing is the simplest and most obvious method of cutting. Use of relatively inexpensive, familiar hand-held tools with favorable operating envelopes makes saws desirable for many applications. The productivity when cutting with saws, however, is relatively low. In general, experience has shown that the use of rotary saws fare better than the use of reciprocating saws. While different saws may be better suited to specific tasks, the ORNL study recommended the abrasive saw for general use based on the following ${ }^{16}$ :

1. Remote blade replacement is straightforward.

2. The probability of blade breakage is significantly less than with a reciprocating hacksaw and about the same as with a band saw.

3. The operating envelope is less than that of the band saw and about the same as that of a reciprocating hacksaw.

4. The effective depth of cut is similar for all three systems.

5. The productivity of the abrasive saw is superior.

This is consistent with the experience at the Pamela Plant, where it was able to increase the cutting rate of stainless steel plate by more than one order of magnitude when it changed from using diamond blades to abrasive grinding discs. ${ }^{7}$

Diamond wire cutting is a method that has been successfully applied to large structures made from a variety of materials of varying hardness. While the cutting itself has been performed remotely, the setup, which can take two times as long as the actual cut, has been performed manually. Conversations with the vendor involved in the TFTR demonstration indicates that as long as remote manipulation is available, the setup could be done remotely. There are several issues concerning diamond wire cutting that may affect its applicability to the dismantling of melters. First, voids in the structure must be filled to maintain structural integrity during cutting. This filling also serves to provide shielding while adding to the amount of waste that must be disposed. Second, the diamond-wire process requires cooling. The TFTR testing looked at multiple methods, with water being preferred one. They system, while retaining most of the water, was not a closed-loop system. The system does result in radioactive liquid. In addition, a small amount of water is carried with the wire and misted over the area. ${ }^{17}$ 
Shearing is superior to the other methods for applications such as cutting tubing, small pipes, electrical cable and conduit. Shears have been modified for remote use with manipulator systems and have resulted in good productivity. Sheet-metal nibblers have also been modified for remote use and have proven to be more productive than sheet-metal shears because of a greater capacity (thicker metal) and the geometric form of the kerf. ${ }^{16}$ The nibbler, is based on a punch-and-die principle and produces individual kerf pieces, while the shears produce a continuous strip which tends to foul in cabling and adjacent equipment. ${ }^{16}$

A melt-gas jet kerf-removal process is appealing because of the ease with which thicker materials can be cut and the resulting increase in productivity. Several different processes are available, including oxy-fuel torches, plasma arc cutting, and arc cutting. Noxious fumes and potential fire hazards (in the presence of a fuel) are disadvantages with these processes. (Recall that one of the lessons learned from the dismantlement of the Pamela melter was that ventilation systems should not preclude the use of plasma torches.) Remotely deployed collection systems, which are to collect or filter noxious fumes, is an issue that requires further investigation.

The oxy-fuel torches works by heating the steel to a high temperature, which causes the steel to readily combine with the oxygen-forming oxides and the metal and then to be disintegrated and burn rapidly. The rate of cutting is dependent on the material thickness, tip size, and oxygen pressure. The carbon content of steel also impacts cutting, since higher-carbon steels require greater preheating. Gases, such as acetylene, gasoline or hydrogen, have been used in these types of torches. As noted previously, oxy-gasoline torches have several advantages over oxy-acetylene torches, including performance in thicker metals, portability, safety, and by-products. While oxy-fuel torches work well with steel, which oxidizes readily, it does not readily cut materials such as cast iron, stainless steel, and other nonferrous materials that do not oxidize as easily. Stainless steel produces oxides that slow the melting-away process. Use of a flux-injection method to inject flux into the oxygen stream can remove the inhibiting oxides, and make the oxy-fuel torch practical for stainless steel as well.

Plasma-arc cutting can be accomplished by using higher currents and gas flow rates, which are typically used for welding. Proximity of the nozzle to the cutting surface is an issue because the high velocities of the plasma jet, which are increased by the restricting nozzle, are used to blow the metal away as it is melted, thus making the cut. The plasma arc process is typically faster than the use of oxy-fuel torches. Recasting of molten metal on the edges can be a problem, but that would obviously not be an issue in D\&D applications.

\subsection{GLASS REMOVAL}

It will be desirable to remove residual glass (because it is HLW) from inside the melter, as well as that splattered outside on support-structure surfaces. Mechanical chippers (such as small jackhammers or pneumatic chisels) have been previously used to remove glass from melters. Removing large quantities of glass using mechanical chipping can be a slow and tedious task because the glass can be difficult to chip off. Operating remotely adds to the difficulty.

Another possible approach to removing large sections of glass is to "score" the glass, thus effectively making a number of smaller sections as opposed to a single large section of glass. At that point, using mechanical chippers may be more productive. Whether such an approach is cost effective or operationally effective would probably require some testing to determine.

SR used beadblasting to remove glass from the IDMS. Adapting for remote operation and handling the residual material will require more investigation. 


\subsection{CP-5 TOOLING EXPERIENCE}

A more detailed description of tooling issues can be found in. ${ }^{8}$ A summary of the key issues is discussed herein. Tools were consumed regularly and were both worn out and broken in operation, as was anticipated. The tool that was used most during reactor vessel sectioning was a heavy-duty circular saw, which was outfitted with a carbide-tipped blade and a vegetableoil-based cooling system. Blades had to be changed periodically, and the saws wore out frequently. Generally, the DAWP was sent into the reactor block with several saws on its deck and did not leave until all the saws were dull or broken. Because the saws were relatively inexpensive to procure locally and were simply outfitted with handles for remote operation, cost per saw was not severe. The general philosophy for remote-tooling support for DAWP at CP-5 was to buy commercially available tools and to outfit them with handles, which were compatible with the Schilling manipulator. Custom tooling or the use of the Schilling tool interface port was not pursued. Although control, positioning, and utilities for tooling would have been easier with the tool interface on the manipulators, the large number and wide array of custom tools required would have been cost prohibitive. Instead, commercially available drills, impact wrenches, cutoff saws, portable band saws, air chisels, and hand tools were modified for remote operation. The only tool that showed promise but could not be adequately deployed was a $3.7 \mathrm{~kW}$ (5-hp) router, which was fitted with a milling bit to provide a hand-held milling machine. The target application was sectioning of the reactor vessel. The operators and the Schilling arms had difficulty with the large and unwieldy tool package, and it was difficult to dial in the cutting speed on the milling bit such that it would cut the aluminum vessel but would not melt the aluminum and foul the bit. Precise positioning was also difficult. In general, tooling and efficiency of operation were an issue. Highly automated tooling would have been too costly and required too much time to adapt and test for the changing CP-5 scenarios; however, using simple tooling without operator assists can be difficult for inexperienced operators. An "in-between" tooling philosophy, which emphasizes smarter tooling with operator assists but does not go so far as to require the costs of full automation would have worked better with the inexperienced operators. 


\section{DISPENSATION OPTIONS}

The focus of this report is on glass-removal methods and disposal strategies, which can match technology and optimal end-states. For a failed glass melter, potential end states include (1) dismantling and repackaging for long-term storage (complete D\&D); (2) long-term storage without undergoing complete D\&D; and (3) refurbishment for possible reuse.

Regardless of the desired end-state, there is a real possibility that the melter will still contain a significant amount of glass material. While still operational, draining of the IDMS melter through the bottom valve failed on multiple attempts due to an inoperative drain valve heater. About $30 \mathrm{~cm}$ of glass remained in the bottom of the 1/10 scale IDMS melter after the final pour. At the Pamela plant, both melters failed when the bottom outlet became blocked. However, at the WVDP, two attempts to drain the melter resulted in only $5 \%$ of the glass left in the melter on each occasion. Based on experience to date, depending upon the melter design and other parameters, there is a reasonable chance that a significant amount of glass will remain in the melter when it is shut down, thus complicating the processing of the melter to its desired end-state.

To reduce the dose level and the subsequent storage and/or disposal requirements would require removal of all the glass in the melter, as well as glass that might have been splattered on the outside of the support structure during operation of the melter. Mechanical chipping, with a tool such as a jackhammer or a pneumatic chisel, has been used for removing glass, but with some difficulty. For example, when removing a significant amount of glass from the IDMS melter, SRS used a number of methods. First, they core-drilled the remaining glass (primarily to get samples for analysis); then it bead-blasted the remaining glass. The bead-blasting, which is like sand blasting but with larger particles, was able to chip away at the glass without damaging the refractory. Mechanical chipping was used to remove the remaining glass. Adapting the bead-blasting and chipping for remote operations would require some issues to be addressed, namely dealing with the bead material, a pneumatic supply for the chipping tool, positioning of the tools, and viewing the work surface.

There is an issue of where the processing of melters to their end-state takes place. Plans for disposal of melters from the DWPF assumed that a separate facility would be made available for D\&D activities sometime after the turn of the century. It was assumed that, when designed, funded, and built, this large shielded facility would have the capability to (1) handle the gross weight of a full melter, (2) reduce the size of the assembly, (3) survey the remains and segregate them into remote-handled and contact-handled waste, (4) containerize them, and (5) ship them out to various destinations. ${ }^{6}$ As previously noted, the melter cell facility itself was used for D\&D of the Pamela melter and other equipment. The D\&D activities were completed in 2.5 years (only 1 of the 2 melters underwent D\&D). Obviously, if the melter cell facility is used for D\&D activities, subsequent vitrification activities must be done sequentially rather than in paralled with the D\&D.

\subsection{REFURBISHMENT}

Recent results from the on-going vitrification efforts at the SRS and WVDP have shown that melter lives have exceeded initial expectations. The ability to refurbish melters offers the potential of additional cost savings. Specifically, refurbishment of melters has the advantages of reusing equipment that has a significant capital investment, minimizing waste, allowing for the reduction in procurement of backup systems and the associated long lead times, and ultimately reducing waste that must be disposed of. 
There may be multiple difficulties associated with refurbishment not the least of which is that the condition of the melter, and the practicality of refurbishing a particular melter may not be readily determinable until after significant effort has been expended. Based on the examination of other melters, the items listed in Table 6 may have to be addressed.

\section{Table 6. Refurbishment issues}

\begin{tabular}{|ll|}
\hline 1. & Significant quantities of glass remain in the melter \\
\hline 2. & $\begin{array}{l}\text { Melter openings, including the bottom drain, pour spout, and feed tubes may } \\
\text { be plugged }\end{array}$ \\
\hline 3. & Thinning and spalling of melt pool refractory, especially along the bottom \\
\hline 4. & Corrosion of the bottom drain valve \\
\hline 5. & Electrodes wear or damage \\
\hline 6. & Cracks and thinning of melt and vapor thermowells \\
\hline
\end{tabular}

\subsection{LONG-TERM STORAGE}

Long-term storage of the melter assembly may be possible, but may not be an acceptable solution. Plans have already been made for temporary storage of failed melters. For instance, at the DWVF the following steps have been laid out for handling of a failed melter ${ }^{6}$ :

- Disconnect the melter from the plant.

- Move the assembly to a remote equipment decontamination cell (REDC).

- Move into a rail-mounted multipurpose container.

- Transfer to a failed equipment storage vault for temporary storage.

If long-term storage is deemed acceptable, then issues concerning removal of high-level waste (HLW) glass and storage location will have to be addressed. Removal of the HLW glass, which remains in the melter before final packaging and the impacts on long-term storage requirements, will need to be addressed. The question becomes: At what point are the storage requirements lessened and is the amount of effort and cost required to reach that point economically and/or otherwise justifiable?

\subsection{COMPLETE D\&D}

Of the melters included in this study, only the Pamela melters have undergone complete D\&D, including remote sizing, packaging, and disposing of waste. Others, such as the IDMS and the SFCM, have been operated, had the glass removed, and have been thoroughly inspected following shutdown. The advantages of completely resizing and repackaging the melter assembly allows for segregation of the waste and a minimization of the stored waste volume.

The primary tasks associated with complete D\&D are decontamination and size reduction. Issues related to both will be briefly discussed. Also of concern is the determination of where the work will be done. Selection of a site for D\&D operations and the type of equipment that will support remote operations are extremely important.

The most obvious task associated with decontamination is the removal of highly contaminated glass. As noted previously, removing the glass from the melter, especially in large quantities, and from the support structure (incidental splatter), is not a trivial task. Methods for removing glass, and the associated tooling, including mechanical chippers, grinders, and saws, were discussed previously in Sect. 5. 
For the task of remote size-reduction, tooling issues are a primary concern. The ability to use the most effective cutting tools, including oxy-fuel torches and plasma-arc cutters, could have a significant impact on efficiency, especially when the amount of material to be handled is considered. Diamond wire cutting is another possible alternative, depending upon the desired disposal approach. While diamond wire cutting has been demonstrated on structures of comparable scale and complexity (excluding the refractory brick), it does add the lightweight concrete used to fill voids to the waste stream.

The approach to be taken certainly will have an impact on the tools required as well. For instance, is the refractory removed before size-reduction of the shell or are these tasks done in reverse order? Will the refractory have to be cut out using diamond-tipped saw blades, or, if the shell is removed first, can a hydraulic jack be used to break-up the refractory? The experience at Pamela was that the shell was removed first and then plans were to use diamond-tipped saw blades to cut out the refractory. However, it was discovered that it was actually much easier to use a simple hydraulic jack to break apart the refractory than to cut the refractory.

The size of the container that can be used for size reduction will also have a significant bearing on operational efficiency. It will determine how much time must be spent cutting pieces up to fit in the containment vessels, obviously from an operations standpoint, the larger the better.

Other lessons learned from the D\&D experience at Pamela are certainly valid and valuable. Of particular significance is the need for the ability to use a variety of different tools and the desire to be able to use more efficient cutting tools, such as plasma torches. It was noted that larger packing drums were needed to reduce time and effort spent on size-reduction. Also worth noting is the recognition that experienced remote manipulator operators are required. Efficient remote operations are highly dependent upon experience. Their findings are consistent with the experience that we have had at ORNL. 


\section{CONCLUSIONS}

There are many issues related to glass removal and how to efficiently process a contaminated melter to the desired end-state. This report has addressed relevant experience and issues and concerns that need to be addressed. Compiling and briefly describing these issues are only the initial step in addressing them.

The first issues are: What is the desired end-state and what are the drivers for reaching that endstate? A related issue is: What facilities are available in which to process the melter to the desired endstate? At DWPF, for example, plans were made early in the program for size-reduction and disposal at a "to be determined" facility. The REDC does not have enough room to access the melter so that it can be processed to the desired end-state condition. A similar situation existed at Pamela, where D\&D activities were actually shifted to the melter cell because of an opening in their scheduled activities.

Regardless of the desired end-state, it has been assumed that removal of the glass from the melter and the support structure will be cost effective. Issues on tooling are unresolved. First, from a facility standpoint, can cutting tools such as oxyacetylene torches and plasma arc cutters be used? Are modifications to filtering systems feasible, practical, and cost effective? Second, what tools will allow for the most efficient removal of the glass and help to minimize the amount of waste that must be treated as HLW? Use of the early scale melters (that were used in simulated waste tests), in conjunction with the on-going remote D\&D work supported by the Robotics Cross Cutting Program and D\&D Focus Area, could provide a means for studying tooling issues and determining the most efficient methods of remote glass removal. These same melters could also be used to determine the best methods for dismantlement and size reduction of melters. 


\section{REFERENCES}

1. D. E. Carl, J. Paul, J. M. Foran, and R. Brooks, West Valley Demonstration Project Vitrification Process Equipment Functional and Checkout Testing of Systems (FACTS), DOE/NE/44139-64, West Valley Nuclear Services Co., Inc., West Valley, New York, 1990.

2. R. Brooks, Slurry Fed Ceramic Melter Disassembly Report, CMH032493, West Valley Nuclear Services Co., Inc., West Valley, New York, 1995.

3. C. C. Chapman and W. P. Drosjack, Vitrification Process Equipment Design for the West Valley Demonstration Project, DOE/NE/44139-42, West Valley Nuclear Services Co., Inc., West Valley, New York, 1998.

4. R. F. Vance et al., Design of Equipment Used for High-Level Waste Vitrification at the West Valley Demonstration Project, DOE/NE/44139-73, West Valley Nuclear Services Co., Inc., West Valley, New York, 1997.

5. C. M. Jantzen and D. Lambert, Inspection and Analysis of the Integrated DWPF Melter System (IDMS) After Seven Years of Continuous Operation, WSRC-MS-99-00336, Westinghouse Savannah River Company, Aiken, South Carolina, 1997.

6. E. C. Norman, P. J. Brackenbury, and J. King, Disposal of Failed Melters from Defense Waste Vitrification Facilities, WHC-SA-1318, Westinghouse Hanford Company, Richland Washington, 1992.

7. M. P. Demonie, Luycx, M. Snoeckx, and L. Baeten, Experience Gained with the Dismantling of Large Components of the Pamela Vitrification Plant, Belgoprocess, Dessel Belgium, 1994.

8. M. W. Noakes, Remote Dismantlement Tasks for the CP5 Reactor: Implementation, Operation, and Lessons Learned, Proc. Spectrum 98 International Conference on Decommissioning and Decontamination and on Nuclear Hazardous Waste Management, Denver, Colorado, 1998.

9. Deactivation and Decommissioning Focus Area,, "Diamond Wire Cutting of the Tokamak Fusion Test Reactor Vacuum Vessel", ITSR OST/TMS ID 2389, U.S. Department of Energy, Office of Environmental Management, Office of Science and Technology, April 2000.

10. Deactivation and Decommissioning Focus Area, "Remote Controlled Concrete Demolition System", ITSR OST/TMS ID 2100, U.S. Department of Energy, Office of Environmental Management, Office of Science and Technology, December 1998.

11. Deactivation and Decommissioning Focus Area, "Compact Remote Operator Console", ITSR OST/TMS ID 2180, U.S. Department of Energy, Office of Environmental Management, Office of Science and Technology, August 2000.

12. Robotics Cross Cutting Program, Deactivation and Decommissioning Focus Area, "Modified Brokk Demolition Machine with Remote Console", ITSR OST/TMS ID 2938, U.S. Department of Energy, Office of Environmental Management, Office of Science and Technology, August 2000. 
13. Deactivation and Decommissioning Focus Area, "Oxy-Gasoline Torch", ITSR OST/TMS ID 1847, U. S. Department of Energy, Office of Environmental Management, Office of Science and Technology, December 1998.

14. Deactivation and Decommissioning Focus Area, "Self-Contained Pipe Cutting Shear", ITSR OST/TMS ID 1948, U.S. Department of Energy, Office of Environmental Management, Office of Science and Technology, November 1998.

15. Deactivation and Decommissioning Focus Area, "Size Reduction Machine", ITSR OST/TMS ID 2395, U.S. Department of Energy, Office of Environmental Management, Office of Science and Technology, April 2000.

16. Personal Communication, 1995.

17. Deactivation and Decommissioning Focus Area, "Diamond Wire Cutting of the Tokamak Fusion Test Reactor Vacuum Vessel", ITSR OST/TMS ID 2389, U.S. Department of Energy, Office of Environmental Management, Office of Science and Technology, December 1998. 
ORNL/TM-2000/324

\section{INTERNAL DISTRIBUTION}

1. J. N. Herndon

2. D. C. Haley

3. C. P. McGinnis

4. B. S. Richardson

5. S. M. Robinson

\section{External Distribution}

6. B. L. Burks, The Providence Group, 10330 Technology Drive, Knoxville, Tennessee 37932

7. L. D. Bustard, Sandia National Laboratories, P. O. Box 5800, MS 0728, Albuquerque, New Mexico 87185-5800

8. E. J. Cruz, U. S. Department of Energy, P. O. Box 550, MS H6-60, Richland, Washington 99352

9. F. Damerow, West Valley Nuclear Services, P.O. Box 91,WestValley, New York 14171

10. J. L. Drake, Jr., U.S. Department of Energy, 10282 Rock Springs Rd., West Valley, New York 14171

11. Tanks Focus Area Headquarters Program Lead, c/o K. Gerdes, U.S. Department of Energy Office of Science and Technology, 19901 Germantown Rd., 1154 Cloverleaf Bldg., Germantown, Maryland 20874-1290

12. P. W. Gibbons, Numatec Hanford Corporation, P. O. Box 999, MSK9-91, Richland, Washington 99352

13. D. Green, U.S. Department of Energy, Oak Ridge Operations Office, P.O. Box 2001, Oak Ridge, Tennessee 37830-8620

14. T. S. Gutmann, U. S. Department of Energy, Savannah River Operations Office, P. O. Box A, Aiken, South Carolina 29802

15. E. W. Holtzscheiter, Westinghouse Savannah River Company, Savannah River Technology Center, Bldg. 773-A, RM A-229, MS 28, Aiken, South Carolina 29802

16. J. O. Honeyman, CH2M Hill (CHG), P. O. Box 1500,MS H6-62, Richland, Washington 99352

17. J. P. Morin, Westinghouse Savannah River Company,Savannah River Technology Center, Bldg. 703-H, Aiken, South Carolina 29808

18. Tanks Focus Area Program Manager, c/o T. P. Pietrok, U.S. Department of Energy, Richland Operations Office, P. O. Box 550, MS K8-50, Richland, Washington 99352 
19. M. T. Terry, Pacific Northwest National Laboratory, P. O. Box 999, MS K9-91, Richland, Washington 99352

20. T. R. Thomas, Lockheed Martin Idaho Technologies Company, P. O. Box 1625, MSIN 3458, Idaho Falls, Idaho 83415-3423

21-28 Tanks Focus Area Technical Team, c/o B. J. Williams, Pacific Northwest National Laboratory, P. O. Box 999, MS K9-69, Richland, Washington 99352 